He, Kai. 2018. "Role Conceptions, Order Transition and Institutional Balancing in the AsiaPacific: a New Theoretical Framework," Australian Journal of International Affairs 72 (2): 92109.

\title{
Role Conceptions, Order Transition, and Institutional Balancing in the Asia Pacific: A New Theoretical Framework
}

\begin{abstract}
The dawn of the twenty-first century witnessed a new wave of multilateral initiatives in the Asia Pacific. By integrating institutional balancing theory and role theory, I propose a new theoretical framework — "balance of roles" — to explain the variations in institutional strategies by different states. I argue that a state's role conception will shape its institutional balancing strategies in an order transition period. An order defender, like the United States, is more likely to adopt exclusive institutional balancing to exclude its target from its dominated institutions. An order challenger, such as China, will choose both inclusive and exclusive institutional balancing to maximize its own power and legitimacy in a new international order. As a kingmaker, a proactive second-tier state is more likely to pick an inter-institutional balancing strategy to initiate new institutions for competing for influence with existing institutions. An institutionalized order transition might be more peaceful than widely perceived.
\end{abstract}

Keywords: Role Theory; Role Conceptions; Order Transition; Institutional Balancing; USChina Relations 


\section{Role Conceptions, Order Transition, and Institutional Balancing in the Asia Pacific: A New Theoretical Framework}

\section{Introduction}

The dawn of the twenty-first century witnessed a new wave of multilateral initiatives in the Asia Pacific. For example, in 2009 Australian Prime Minister Kevin Rudd proposed the idea of the Asia Pacific Community (APC) and Japanese Prime Minister Yukio Hatoyama advocated an East Asian Community (EAC). In 2013, Korean President Park Geun-hye proposed the Northeast Asia Peace and Cooperation Initiatives (NAPCI) to strengthen regional security cooperation. In 2013, Chinese President Xi Jinping also suggested the building of a "community of common destiny" (CCD) in Asia, along with massive Chinese investments and financial initiatives, such as the "Belt and Road Initiative" (BRI). Even the United States under the Obama administration actively engaged with this new wave of multilateralism in the Asia Pacific. For example, the United States under the Obama administration has played a leadership role in promoting the Trans-Pacific Partnership (TPP), a high-standard trading bloc consisting of 12 countries despite the fact that the rise of Trump has killed the TPP in its infancy.

Although some initiatives and ideas have become "thought bubbles," like Rudd's APC and Hatoyama's EAC, these countries' efforts in promoting this new wave of multilateralism deserve serious scholarly inquiries. In the 1990s, ASEAN (Association of Southeast Asian Nations) played a leadership role in promoting multilateralism in the Asia Pacific. Will this new wave of multilateralism challenge ASEAN's “driver's seat" for multilateralism in the region? More precisely, will China's multilateral initiatives facilitate the emergence of a new regional order? Will Australia, Korea, and Japan use multilateralism to balance China's growing influence in the future? After Donald Trump came to power, his "America first" policy seemed to drive the United States back to isolationism. Multilateralism, therefore, will become even more important in structuring regional economic and security architecture in the Asia 
Pacific. It is imperative for both scholars and policy makers to better understand how states pursue their national interests through multilateralism.

Through integrating institutional balancing theory and role theory, I propose a new theoretical framework — "balance of roles" — to explain the variations in institutional strategies by different states. I argue that a state's role conception will shape its institutional balancing strategies in an order transition period. Specifically, an order defender like the United States is more likely to adopt exclusive institutional balancing to exclude its target from its dominated institutions. China, as an order challenger, will choose both inclusive and exclusive institutional balancing to maximize its own power and legitimacy in a new international order. As a kingmaker, a proactive second-tier state is more likely to pick an interinstitutional balancing strategy to initiate new institutions to compete for influence with existing institutions.

There are three sections in this paper. First, I clarify my definition of international order and order transition. I suggest that an order transition has two interrelated processes: a power shift and an institutional transformation. It is why states not only fight for material power through traditional military means, but also compete for influence and dominance in multilateral institutions through institutional balancing strategies. Second, by integrating role theory and institutional balancing theory, I propose a "balance of roles" framework to explain different institutional balancing strategies during the order transition period. Third, I briefly discuss how the United States, China, and other major powers (Australia, Japan, and South Korea) have conducted institutional balancing after the 2008 Global Financial Crisis (GFC). In conclusion, I argue that an order transition based on institutional balancing might be more peaceful than widely predicted. 


\section{International Order and Order Transition}

International order has been a contested concept in International Relations (IR). As Joseph Nye Jr. (2003) points out, different IR theories have different emphases in defining international order. While realists see international order primarily through the structure or distribution of power among states, liberals link it with institutions and rules. For constructivists, "any order is contested by various parties and thus is never a value-neutral term" (Nye, 2003: 250). One popular definition from the English School suggests that international order is "a pattern of activity that sustains the elementary or primary goals of the society of states, or international society" (Bull, 1977: 8).

In this paper, I choose a synthesized definition of international order by Henry Kissinger (2014: 9), who defines international order with two components: "a set of commonly accepted rules that define the limits of permissible action and a balance of power that enforces restraint where rules break down, preventing one political unit from subjugating all others." In other words, institutions and balance of power are the two major features of international order. It is worth noting that Kissinger also highlights the importance of "legitimacy" — a normative feature of order by suggesting that "A consensus on the legitimacy of existing arrangements does not - now or in the past-foreclose competitions or confrontations, but it helps ensure that they will occur as adjustments within the existing order rather than as fundamental challenges to it" (Kissinger, 2014: 9). It is clear that, according to Kissinger, the rules of institutions entail the legitimacy of the order, which guides and constrains state behaviour among each other.

There are two reasons for adopting Kissinger's definition of international order in this paper. First, as mentioned above, Kissinger's definition of international order synthesizes major underpinnings of three IR paradigms on international order: balance of power from realism, rules and institutions from liberalism, and legitimacy from constructivism. Kissinger 
seems to link the legitimacy and institutions together while highlighting the independent role of power in defining international order. This is understandable given Kissinger's reputation as a realist scholar and practitioner. The second benefit of choosing this definition is that it is easy to operationalize in analysing the "order transition." As Kissinger (2014: 365) suggests, "every international order must sooner or later face the impact of two tendencies challenging its cohesion: either redefinition of legitimacy or a significant shift in the balance of power." Since Kissinger treats legitimacy as being rooted in institutional arrangements, we can derive two necessary conditions to measure an order transition, which are institutional transformation and power shift. ${ }^{1}$

It means that an order transition will take place if both the major rules and institutions or the power distributions in the system have been changed. Traditional power transition theorists are right to suggest that the material power shift will lead to the rise and fall of great powers (e.g. Organski, 1958; Organski and Kugler, 1980). It is why states are extremely sensitive to the power balance in the international system. However, one less-studied topic is institutional competition or institutional balancing among states, which can also play an important role in instigating an order transition. In fact, these two conditions of order transition are interrelated and enforced by one another. On the one hand, institutional changes might escalate a power shift in the system. On the other, a power shift among states will also cause an institutional transformation. For example, the dissolution of the Warsaw Pact can be seen as both the cause and consequence of the Soviet Union's power decline by the end of the Cold War.

In a similar vein, the United States hegemony is also built on both its preponderant military power and the Bretton Woods institutions, including the World Bank and International

\footnotetext{
${ }^{1}$ It is worth noting that whether Kissinger's conceptualization of "international order" is useful is still a debatable question. The author is fully aware of different views and concepts of international order.
} 
Monetary Fund (IMF) (Ikenberry, 2001; 2011). The US power experienced ups and downs in the 1950s and 1970s, but the degree of these power shifts was not significant to change the distribution of power during the Cold War, i.e., the bipolar system. The collapse of the Soviet Union, however, fundamentally changed the power distribution in the system and the international system consequently changed from bipolarity to unipolarity after the Cold War. However, since the US-led Bretton Woods institutions did not change, the order transition is only partial in nature after the Cold War. I suggest that the end of the America-led liberal order will take place when both US military power declines and the Bretton Woods institutions collapse.

The two processes of power transition and institutional change normally occur together although some liberals insist that the United States power decline does not mean the end of the liberal order (Ikenberry, 2008). During the order transition period, states will fight for both material power and institutional domination. Material power is easy to understand because a ruling power or hegemon will not just give up its dominant position in the distribution of capabilities that a rising power is eager to get. Therefore, as power transition theorists suggest, war or military conflict is more likely to take place between a ruling power and a rising power. Graham Allison (2017) recently labels this phenomenon as "Thucydides's trap," which has attracted great attention from both academic and policy communities.

In this paper I would like to focus on the less-studied competition-institutional balancing - among states during this order transition era. As mentioned above, order transition is not all about power. Instead, institutions and rules are also an important arena for great powers to compete. Institutional balancing refers to a new type of balancing behaviour for states to pursue their realist agendas, such as power and influence, through multilateral institutions in the anarchical international system (He, 2008; 2009). Like power competition or power balancing, institutional balancing is not a unique phenomenon during an order transition. 
However, a potential order transition or a shared perception of order transition will intensify institutional balancing among states just like heated power competition between ruling states and rising powers during a power transition time.

There are three types of institutional balancing: inclusive institutional balancing, exclusive institutional balancing, and inter-institutional balancing (He, 2014; 2015). Inclusive institutional balancing refers to the strategy of including a target state in a multilateral institution. The rules and norms of this multilateral institution will be used to constrain and shape this target state's behaviour. For instance, the ARF (ASEAN Regional Forum) was designed to constrain or socialize China's policy behaviour in the 1990s (Foot, 1998). Exclusive institutional balancing refers to excluding a target state from an existing institution. The cohesion and cooperation of this institution will exert pressures or countervail threats from the target state. The APT (ASEAN Plus Three) is a good example of Asian countries' exclusive institutional balancing against the United States after the Asian financial crisis (Stubbs, 2002; Beeson, 2003).

Inter-institutional balancing is an extended form of institutional balancing. It can be either inclusive or exclusive in nature. The unique feature of this "inter-institutional balancing" is not the "goal" of institutional balancing, but the "means" of institutional balancing. For this "inter-institutional balancing," a state not only initiates a new institution, but also intends to use this new institution to replace, not co-exist with, the old one. In other words, the direct target of inter-institutional balancing is not only an individual state per se. Instead, it is another existing institution and it is a balancing game between a new institution and an existing institution.

For example, the establishment of the East Asia Summit (EAS) is widely seen as a rival institution of the APT although the EAS is indeed an extended form of APT. It is obvious that some states in the APT, especially Japan and Singapore, are concerned that given China's 
increasing economic power China will eventually dominate the APT (Simon, 2008; Hughes, 2009). Therefore, they advocated to expand the APT to the EAS by admitting three new members, Australia, New Zealand and India so that China's power and influence will be diluted in a bigger institution as well as constrained by new members. Therefore, promoting the EAS is an inter-institutional balancing strategy aiming to reduce the power and influence of the APT as well as China in the regional economic and security architecture.

It is worth noting that scholars have suggested many institutional strategies, such as economic engagement and omni-enmeshment (Goh, 2007). I intend to subsume all these institutional strategies with my institutional balancing argument. Just like "balancing of power" in IR that can include many strategies, such as alliance formation, arms building, and containment, institutional balancing entails many detailed strategies. Particularly, I argue that economic engagement and omni-enmeshment are different types of "inclusive" institutional balancing, through which a state can constrain a target state's behavior within a certain institution. While omni-enmeshment implies a process of socialization, I suggest that institutional balancing, i.e., constraining target states within institutions, will be the first step for later socialization process if it indeed happens.

As I mentioned previously, there has been proliferation of a new wave of multilateralism in the Asia Pacific after the 2008 GFC. The GFC is widely seen as the beginning of the end of the Western order. As Zakaria (2008) points out, "In April [2008], a new poll revealed that 81 per cent of the American people believe that the country is on the 'wrong track." This widespread pessimistic view is not unwarranted. Although the United States is still the most powerful country in military terms, "along every other dimensionindustrial, financial, social, cultural — the distribution of power is shifting, moving away from American dominance" (Zakaria, 2008). This perceived power transition or the end of Pax Americana after the GFC has led major powers including the United States, China, Japan, 
Australia, and South Korea, to actively conduct institutional balancing toward one another through either initiating new multilateral institutions or reinvigorating some existing ones.

One interesting question is: why do states choose different institutional balancing strategies during the order transition era? For example, the United States under the Obama Administration actively promoted the TPP - an existing but small-scale multilateral trading bloc - to technically exclude China due to its high admission conditions, especially on labour standards and state-owned enterprises. It is a typical exclusive institutional balancing move, using the cohesion of the TPP to reduce China's influence in economic affairs. When China proposed a new bank, the Asian Infrastructure Investment Bank (AIIB), to fill much-needed infrastructure gaps in Asia, the United State also refused to join. It is a self-selected exclusive institutional balancing strategy, through which the United States intended to block or sabotage China's institutional building efforts.

China's institutional balancing strategies, however, are more flexible and inclusive. For example, its AIIB proposal is open to all countries, including the United States and Japan. Similarly, Xi's CCD does not have any membership restrictions, although regional responses are somehow lukewarm and even cold. Other major powers, including Japan, South Korea, and Australia, all proposed some new institutions, such as Hatoyama's EAC, Park's NAPCI, and Rudd's APC. These new institutions, despite their unfortunate outcomes later, constitute an inter-institutional balancing strategy which aims to compete for influence with existing institutions, such as the EAS, APT, and ARF.

\section{Balance of Roles and Institutional Balancing Strategies}

I propose a "balance of roles" argument, integrating institutional balancing theory and role theory, to explain the various institutional balancing strategies of the United States, China, Australia, Korea, and Japan after the GFC. Role theory is a research programme that includes many models and perspectives sharing a similar view on the importance of the concept of role 
in social life. The "role" concept is a metaphor borrowed from the theatre. Role theorists suggest that everyone plays a certain societal role or roles through which society functions as a web composed of the roles of individuals. The term "role is defined as both a position in an organized group and any socially recognized category of actors" (Stryker and Statham, 1985: 323; see also Thies, 2010). Role theory was first introduced to foreign policy analysis and international relations in the 1970s (Holsti, 1970; see also Walker, 1987; 2013; Harnisch, 2012; He and Walker, 2015). As Cameron Thies (2010) suggests, role theory has the potential to link different levels of analysis within the subfield of Foreign Policy Analysis as well as to connect agents and structures in the IR field, although the intellectual value of role theory is also either overlooked or questioned in the IR field.

There are two reasons for applying role theory in the studies of state behaviour during the international order transition. On the one hand, international order transition is a complicated process, which cannot be grasped by any single theoretical perspective. As mentioned before, Kissinger's definition of international order embraces all key elements of realism, liberalism, and constructivism. Role theory provides a unique framework to integrate different theoretical perspectives to address this complex feature of order. For example, the "position" part of a state's "role" definition captures the military and economic capabilities of a state in the international system. The "recognition" part of the "role" definition gives a socially constituted meaning to a state versus others in an international society.

On the other hand, role theory is flexible enough to incorporate other theories employed in studies of foreign policy. As mentioned before, role theory is not a single theory. Instead, it is a set of models within a research approach or program, which highlights the significance of a state's "role" in shaping its behaviour. As Thies points out, many foreign policy scholars have integrated role theory with other theories in the study of international relations and foreign policy. For example, Stephen Walker (1981) integrates role theory with exchange theory to 
model the dynamic processes of "role location" for a state in the social structure. Role location is a term to describe the process through which an actor, such as a state, selects a role that fits a social environment. Similarly, Thies $(2012 ; 2013)$ integrates the concept of role with socialization theory to model how rising powers negotiate their new roles with existing powers in an international society.

In this study, I integrate role theory with institutional balancing theory to explain the variations of institutional balancing strategy during an order transition era. One major argument of role theory is that the role conception of a state shapes its role enactment. While role conception refers to a state's identification of its own role, the concept of role enactment means how a state performs its role. In plain language it suggests that how a state perceives its role (role conception) in an international society will influence its behaviour (role enactment). For example, since the Soviet Union perceived itself as the leader of the international communist movement (and it was also recognised as such by others), it became involved in domestic affairs in Eastern Europe during the Cold War. Similarly, because the United States perceived itself and was also recognized by others as a leader of global anti-communism during the Cold War, it fought the Vietnam War to prevent the "domino effect" of spreading communism in Southeast Asia.

One key to applying role theory in foreign policy analysis is to define the role conceptions of states. However, it is not straightforward to measure a state's role conception. Three potential problems will need to be considered in identifying a state's role conceptions. First, like individuals in a society, a state has multiple roles in an international society at the same time. In his ground-breaking work, Holsti (1970: 260-270) identifies 17 major roles expressed by states between 1965-1967, such as revolution-liberator, regional leader, liberation supporter, and mediator-integrator. The average number of roles for each state was 4.6, with a range of 0 (Ivory Coast) to 8 (USA). Therefore, it is important for role theorists to clearly 
identify the major role that a state selects to enact within a particular context, i.e. the role that will shape its behaviour toward different states. If a state enacts two or more contradictory roles, then the inter-role conflict will normally lead to a conflictual outcome.

For example, Barnett (1993) suggests that conflicts in the Middle East prior to 1967 were rooted in the incompatible dominant roles for states as either sovereign states or panArabist states. In a similar vein, China is also facing potential "inter-role conflicts." On the one hand, China is the second largest economy in the world, which gives it a "great power" role in world politics. On the other, China is also the largest developing country, a position which should be seen as a second-tier power if measured by GDP per capita. This inter-role conflict between the great power role vs. the second-tier role might explain some contradictory policy behaviours of China in world politics (see Harnisch, Bersick and Gottwald, 2015).

Second, who determines a state's national role conception is also an important question for role theorists. Normally, role theorists use top leaders' speeches and statements to code a state's national role conceptions. This is fine if the top leaders have a consensual view as well as strong control in a centralized political system. In a pluralistic political system it might be problematic because other political actors, such as opposition parties, can have different role conceptions from top leaders; the top leaders themselves also might have different views on which role their country should choose in foreign policy. This situation is called "role contestation" among domestic actors (Cantir and Kaarbo, 2012). The role contestation among domestic actors will complicate the process for a state to select national role conceptions.

Last but not least, when or under what conditions a state changes its national role conception is also important for applying role theory to foreign policy analysis. Will a domestic leadership transition lead to a change of national role conceptions? Will a political leader change his or her previously selected national role conceptions? These are important empirical 
questions for role theory scholars to consider in their research since different countries have different political systems and political cultures.

For example, despite the regular power transition between the Democratic Party and the Republican Party, the United States seems to have a relatively stable national role conception as a hegemon in the post-Cold War era because all US Presidents, to a different degree, emphasize US leadership as a hegemon in their official speeches. On the contrary, different Australian leaders seem to have different views on national role conceptions, i.e. what kind of role should Australia play in the world? For example, Kevin Rudd was ambitious in promoting an active and independent diplomacy through the APC proposal. In comparison, John Howard, Rudd's predecessor, was famous for his statement to label Australia as a "deputy sheriff” of the United States in 1999. Apparently, Australia's national role concept under Rudd was different from that under Howard.

During an order transition era, major powers will re-examine their respective role conceptions in the context of strategic uncertainties along with the order transition. The fundamental goal of states is still the same, i.e. to maximize their security first and then pursue more power and influence when it is possible. As mentioned before, institutional arrangements and rules are one of the major components of international order besides material power. Although power transition between rising powers and ruling powers will impact international order, the significance of institutional arrangements and rules cannot be overlooked. It is why some liberals contend that the United States should constrain China within the current liberal order, because the liberal order will endure even after the US hegemony declines (Ikenberry, 2008).

Another reason for states to care about institutional arrangements is more cognitive. As Kissinger (2014: 366) points out, "the essence of such upheavals (during an order transition) is that while they are usually underpinned by force, their overriding thrust is psychological. 
Those under assault are challenged to defend not only their territory but the basic assumptions of their way of life, their moral right to exist and to act in a manner that, until the challenge, had been treated as beyond questions." Here, the "way of life" and "moral right to exist" are embedded in the institutional arrangements and principles. Therefore, I suggest that states will actively engage in institutional competition during the order transition through various institutional balancing strategies to secure their advantageous positions in the future international order.

How states will conduct institutional balancing is mainly shaped by their role conceptions in the order transition process. There are three types of role conceptions in an international order: order defender, order challenger, and kingmaker. An order defender sees itself as part of the existing order and will try its best to keep the order intact. An order challenger, by definition, pursues a transition of the current order. It is worth noting that transition is different from adjustment. While the former refers to a fundamental change of the nature of the international order, such as leadership or institutional principles, the latter means some technical alterations of auxiliary parts in the international order. For example, the expansion of membership in World Trade Organization (WTO) is a technical change in the international trade regime. However, if the WTO collapses in the future, it will be a fundamental transition of the trade regime in the world.

The third type of role is to be a kingmaker. It refers to a proactive role that a secondtier state can play during the order transition. Due to its limited power capabilities, a kingmaker state will not be able to compete for leadership in the future international order. However, it can play an important role in facilitating either the existing hegemon's defence of the current order or a rising power's challenge to the existing order. It is clear that not all second-tier powers or middle powers are able or willing to play this role. Soon after the Cold War, ASEAN played this kingmaker role by establishing the ARF and other ASEAN-oriented institutions to 
fill the power vacuum in the Asia Pacific. Although ASEAN by no means played a leadership role in regional security, its importance is reflected by the fact that it was wooed by both the United States and China in the post-Cold War era.

It should be clear that a role conception is not simply determined by material power capabilities of states, as assumed by realists and especially power transition scholars. Although a hegemon as the order defender and a rising power as the challenger seem coincident with the dichotomy between status quo vs. revisionist states, role theory emphasizes the "intersubjectiveness" of role identity. It means that the role conception is shaped by both self-role identification (a material position in the system) and others' role acceptance (social recognition). The convergence of self-role identification and role acceptance by others will lead to a successful role conception for a state. The divergence of role identity between self and other will cause role bargaining between the state and the outside world (Thies 2013).

For example, China has been seen as a rising power or revisionist state since the end of the Cold War. However, Chinese leaders have tried hard to convince the rest of the world that the rise of China would be peaceful or that China was not a challenger. To ease the suspicions from the outside world, the Chinese government even changed its official slogan of "peaceful rise" to "peaceful development" in 2004 (Glaser and Medeiros, 2007). It suggests that China did not perceive itself as a challenger to the international order although the outside had widely perceived China as a revisionist power. ${ }^{2}$

After the 2008 financial crisis, Chinese leaders have started to change its national role conception. At the 2009 Davos World Economic Forum, Chinese Premier Wen Jiaobao harshly criticized "inappropriate macroeconomic policies" of some unnamed countries and the "unsustainable model of development characterized by prolonged low savings and high

\footnotetext{
${ }^{2}$ I acknowledge that other scholars might have different interpretations regarding China's change of slogan from "peaceful rise" to "peace development."
} 
consumption." Given the origin of the financial crisis in the United States, everyone knows which country was in Wen's mind. Echoed by Russia, China started to demand a "bigger role" in a new economic order (Edgecliffe-Johnson et. al., 2009). In March 2009, Chinese Central Bank Governor Zhou Xiaochuan publicly called for replacing the dollar as the dominant world currency and creating "an international reserve currency that is disconnected from individual nations and is able to remain stable in the long run." It is clear that Zhou's talk targeted the United States. Therefore, we can argue that China's role conception has changed from "selfdenied" challenger to "self-confirmed" challenger since the 2008 GFC.

China's role as a challenger to US leadership in the current international order is also confirmed by the outside world. For example, in his 2015 State of the Union speech President Obama (2015) singled out China as the challenger to the United States in global governance by stating that "China wants to write the rules for the world's fastest-growing region... Why would we let that happen? We should write those rules. We should level the playing field." In an even more alarming tone, two leading policy analysts in Washington assert, "a longterm strategic rivalry between Beijing and Washington is high" and China is "the nation most capable of dominating the Asian continent and thus undermining the traditional U.S. geopolitical objective of ensuring that this arena remains free of hegemonic control"' (Blackwill and Tellis, 2015). It is clear that China's "challenger" role is not solely determined by material power but mutually constructed by self's role conception and other's role acceptance.

Through integrating role theory and institutional balancing theory, I propose a balance of roles framework to explain the various institutional balancing strategies during a power transition era. Table 1 summarizes the relationship between role conception (Independent variable) and institutional balancing strategy (Dependent variable). I suggest that a state's role conception as the order defender, the order challenger, or the potential kingmaker, will shape its institutional balancing choices during an order transition time. 
[Table 1 Here]

I suggest that the perceived "legitimacy" of international order is a causal mechanism between role conception and institutional strategies. Here, I follow Ian Hurd to define legitimacy as "the normative belief by an actor that a rule or institution ought to be obeyed" (Hurd 1999, 381). Role conception is also a normative belief that an actor has regarding its position in a socially constructed environment. Just because of the environment is socially constructed in nature, different actors have different perceptions about the "legitimacy" of institutions as well as international order in general.

An order defender is inherently the "holder of legitimacy" of institutions. It does not want to share this "legitimacy" with others. It is why an order defender does not like any possible changes in the existing order. Therefore, an order defender is more likely to choose an exclusive institutional balancing strategy toward any institutional challenges from rising powers. It also keeps rising powers out of its own institutions so that the influence and legitimacy of a rising power will be undermined. It can also decline to endorse and join any new institutions that are initiated by rising powers, i.e. exclude itself from institutions. The purpose of this self-exclusion strategy is to deny the legitimacy of any new institutions and institutional challenges from rising powers.

For an order challenger, its fundamental goal is to gain legitimacy from others. Therefore, it has more flexibilities to choose either or both institutional balancing strategies as long as they can facilitate to gain more "legitimacy" from the order defender. Further, I suggest that (1) an order challenger will adopt an inclusive institutional balancing if it enjoys relative advantages versus the order defender. (2) the rising power challenger might also choose 
exclusive institutional balancing if it believes that it has relative disadvantages versus the order defender (see Feng and He 2017)

In particular, a rising power is more likely to reinvigorate an existing institution or create a new one, because the rules and principles of the old institutions were set by the hegemon or ruling power when the rising was still weak. Through reviving an existing or setting up a new institution, the rising power can modify institutional arrangements and set new agendas according to its interests. However, the new institutional arrangements must be accepted and recognized as a legitimate alternate to the existing ones by a majority of states. Therefore, when a rising power has relative advantages in a certain issue area, it is more likely to conduct inclusive institutional balancing to invite all countries, including the existing hegemon to join, so that the new institution can gain as much legitimacy as possible in the order transition era. When a rising power does not have relative advantages versus others, it is more likely to choose exclusive institutional balancing to keep the existing hegemon out from institutions it dominates because including the hegemon will further erode its inherently weak legitimacy in the institutions.

As kingmaker, a state will need to play an active, more importantly, independent role in institutional building during the order transition. Therefore, it is more likely to choose an inter-institutional balancing strategy to establish or support a new institution that is different from the existing one but embrace both the hegemon and rising powers. On the one hand, a kingmaker state will enjoy more leverage in an institution it creates. By including both the hegemon and rising powers, the kingmaker can create a balance between the two parties and make itself the centre of attention. On the other hand, this new institution can ensure that it can reap all the benefits of the new international order if one inevitably emerges.

\section{Institutional Balancing after the GFC}


Since the 2008 GFC, the current international order has faced tremendous pressures and challenges. This section will apply the "balance of roles" framework to examine the institutional dynamics during the order transition. As I mentioned before, measuring a state's national role conception is complicated since we need to consider the role contestation among different domestic actors as well as the inter-role conflict among a state's multiple role conceptions. Therefore, the following analysis serves as an analytical probe and a preliminary test of the validity of the "balance of roles" argument. I make a simple assumption that we can clearly define a state's major dominant role conception in the order transition although I encourage other researchers to explore the complex processes of role contestation and role conflict leading to role location for individual states in future research.

I suggest that the United States as the hegemon perceives itself as the defender of the existing order and intends to maintain its leadership in either the existing order or in a new order if order transformation is inevitable. China, on the other hand, identifies itself as a challenger of the old system, pursuing a new leadership in a new order. For other states, such as Japan, South Korea, and Australia, they do not have the capability to compete for a leadership role in a new order, but they can potentially become the kingmaker, which can facilitate them in pursuing an advantageous position in the new order.

The United States as the existing leader or order defender does not want to see any change in the order because it has enjoyed all the privileges of leadership for a long time. This describes exactly the position of the United States towards multilateralism after the Cold War. As Paul Kennedy (2010) observes, "Hegemons always prefer History to freeze, right there, and forever. History, unfortunately, has a habit of wandering off all on its own." Because the United States is worried that any multilateral institutions can potentially harm its established "huband-spokes" security arrangement, it was initially passive toward the establishment of the ARF led by the ASEAN. 
The United States eventually changed its attitude, because the ARF provided a unique platform to engage China as well as cope with non-traditional security issues (Goh, 2004; Katsumata, 2010). However, it was still hesitant to embrace other multilateral institutions in the Asia Pacific. This strategic reluctance explains why the United States refused to join the EAS in the early 2000s. In 2011, the United States eventually joined the EAS. One of the reasons for the United States participation in the EAS was to regain its lost influence in Southeast Asia as well as to balance against China's potential domination in the region (Zhao, 2015; Ikenberry, 2016; Bisley, 2017).

Therefore, this existing “order defender" role constrains US behaviour in initiating new multilateral institutions, because any new initiative might threaten the relevance of existing institutional arrangements, especially the "hub-and-spokes" system. Moreover, the United States has strong incentives to de-legitimize any challenges from rising powers through multilateral institutions. Therefore, as the "balance of roles" model previously suggests, exclusive institutional balancing is a preferred strategy for the hegemon or the order defender during the order transition period. For example, the United States under the Obama administration actively promotes the TPP, which was originally a four-country trade agreement among Brunei, Chile, Singapore, and New Zealand in 2005. Since 2008, the Obama Administration had actively joined the TPP negotiation aiming to establish a trading bloc in the Asia Pacific. Because of its high entry standards, China was intentionally excluded by the TPP (see Lieberthal and Wang, 2012; Green and Goodman, 2015; Perlez, 2015). Consequently, the United States TPP strategy can be seen as an exclusive institutional balancing strategy against China's growing influence in the region.

In a similar vein, US passive attitude toward the AIIB can also be seen as an exclusive institutional balancing strategy of the United States to de-legitimize China's potential leadership role in financial governance. Given its preponderant economic power, US 
recognition had been seen as a key for the success of any new multilateral financial institutions in the Asia Pacific. For example, Japan's failed attempt at establishing the Asian Monetary Fund (AMF) after the Asian financial crisis was mainly caused by US objections (Lipscy, 2003; Lee, 2006). Therefore, it was clear that the major reason for the United States to say "no" to the AIIB is to de-legitimize China's efforts in challenging the existing financial order based on the Bretton Woods system, just as it used the same strategy to successfully defeat the AMF (Ikenberry, 2016). Although the outcome of the AIIB seems beyond the expectation of the United States, its refusal to join the AIIB follows the logic of exclusive institutional balancing.

It is worth noting that the evolution of US institutional strategy toward China also vindicates the added-value of role theory in shaping the hegemon's institutional approaches in the balance of roles framework. After the Cold War, the US conducted two types of institutional strategies toward China. In the 1990s and early 2000s, the United States actively engaged China through institutions, such as the WTO. It is "inclusive institutional balancing" through which the United States intends to use institutions to constrain or even socialize China's behavior (Johnston 2014). However, as mentioned before, the United States started to change its institutional balancing strategy especially after the GFC from "inclusive" to "exclusive" in that the United States refused to join the AIIB and tried to keep China out of the TPP. Why did the United States change its institutional balancing strategy after the GFC? Role theory can shed some light through changing role conceptions. A simple answer is that the United States did not view China as an "order challenger" before the GFC and it is why it was willing to use institutions to constrain China. However, when China became an "order challenger" after the GFC and the US felt the threat of its legitimacy in the current order, an exclusive institutional balancing strategy makes more sense since it will better defend the "legitimacy" of the US in the current order. 
As the "balance of roles" model suggests, China as a challenger has more options in selecting different institutional balancing strategies, because it does not have the burden of the past or the existing system. China can adopt both inclusive institutional balancing and exclusive institutional balancing to challenge US leadership in the existing order. The major goal of a challenger is to compete for an advantageous position as well as establish its own legitimacy base in the new international order. In the security arena, where China still lags far behind the United States, China chose exclusive institutional balancing to exclude the United States from the institutions it dominated. For example, China established the Shanghai Cooperation Organization (SCO) to strengthen security cooperation with Russia and Central Asian countries with the participation of the United States. In addition, China reinvigorated CICA (Conference on Interaction and Confidence Building Measures in Asia), an old security institution initiated by small Central Asian countries, in 2014 as an exclusive institutional balancing strategy to countervail security pressures from a United States "pivot" and "rebalancing" effort, which started in 2011 (Anderlini, 2014).

However, as a challenger of the existing order it is not in China's interests to overthrow the whole system, because it is also a beneficiary of the current economic order. Therefore, in the economic arena, where China has enjoyed some relative advantages due to its rapid and sustained economic growth, China adopts inclusive institutional balancing to use existing institutions for constraining and shaping US behavior, as it has done through active participation in existing institutions such as the EAS and ARF. Moreover, China actively promoted the establishment of the Asian Pacific Free Trade Agreement (APFTA) on the basis of APEC, which also includes the United States.

The APFTA is China's inclusive institutional balancing through which China will play a leadership role in writing new trading rules for constraining US behaviour. It was apparently not welcomed by Obama, who clearly emphasized that the United States did not want to live 
under trading rules written by China. In other words, the United States does not want to live in a new order under the Chinese leadership. As mentioned before, China's original proposal of the AIIB was also intended to include the United States and Japan, the two major players in financial governance in the Asia Pacific because it will boost the international legitimacy of the AIIB as well as China's potential leadership role in the future economic order. Understandably, neither the United States nor Japan supported China's AIIB proposal, because the best way for an order defender such as the United States to defeat an order challengerChina - is to deny the legitimacy of China's leadership in the AIIB. This pattern follows the logic of the "balance of roles" framework.

For other major powers their self-identified role should be "follower" by default. It means that they can either follow the hegemon as an order defender or they can become an order challenger as a rising power does. However, this follower role has the potential to become a kingmaker if its occupants adopt an appropriate and independent institutional strategy during the order transition. Depending on how these countries bet on the future leadership, they will adopt different policies. For example, it seems that Japan under the current Abe administration still believes that the US leadership is unchangeable in the future. Therefore, supporting US policy becomes a key principle in Japan's current foreign policy, and Japan under Abe is playing a "follower" role in support of the US liberal order in the system.

In the process of order transition, betting on any side will be a risky policy. Therefore, the best strategy is to become an active "kingmaker" instead of a mere follower in this order transition period. Institutional balancing becomes a useful diplomatic tool for these second-tier powers to play a more active role in shaping a new regional order. Due to their dissatisfaction with the existing institutions, the kingmaker states are more likely to adopt an inter-institutional balancing strategy to strengthen and highlight their relevance in the future international order. As mentioned before, ASEAN has actually seized a similar strategic opportunity brought about 
by the end of the Cold War. It has built up many ASEAN-centred multilateral institutions, such as ARF, APT, and EAS, and played a pivotal role in shaping the regional architecture in the 1990s and the 2000s (He, 2008; 2009).

Since these ASEAN-centred multilateral institutions still exist, Japan, Australia, and South Korea as second-tier powers have to initiate and develop new institutions to "steal the thunder" from ASEAN during the regional order transition. This is why Hatoyama, Rudd, and Park all initiated new multilateral institutions, including the EAC, APC, and NAPCI, respectively, after the 2008 GFC. It is an inter-institutional balancing strategy through which these new institutions can potentially replace the existing ASEAN-dominated institutions in the future regional order. Because these countries initiated these competing institutions, the success of the institutions will offer them tangible benefits in agenda-setting and rule-making within the institutions. Although they will not have the capability to seize the leadership role, this institutional privilege will maximize their interests as a "kingmaker" in the future international order.

Unfortunately, the above mentioned multilateral initiatives all failed to materialize due to the domestic leadership shifts in Australia, Japan, and South Korea. The new leaders in these second-tier powers will select a new national role conception for their countries, based on their own understandings and beliefs on the future order transition as well as the power balance between the United States and China. As the "balance of roles" model suggests, not all secondtier powers can be kingmakers during an order transition. Only aspiring and forward-looking political leaders can take up this challenge; others will select a passive follower role. Moreover, the past failed outcome of these institutional balancing efforts cannot be used to refute the future institutional strategies by these second-tier powers. The successful institutional buildings in the 1990s by ASEAN — a group of middle and small powers - suggest that second- 
tier powers might be able to play a more active and important role in fostering multilateralism in the future "order transition" period.

\section{Conclusion}

The 2008 GFC has signified the start of international order transition. In Zakaria's terms (2008), international politics entered the "post-American world" after 2008. The United States, China, Australia, Japan, and Korea have all engaged in different forms of multilateralism during this "order transition" period. Although there are both successful cases and failed attempts, it is clear that multilateralism will remain an important form of state behaviour and interaction in the future.

By integrating role theory and institutional balancing theory, I have proposed a "balance of roles" argument to explain the various institutional balancing strategies of the United States, China, and other major powers during the order transition era. It suggests that the United States, as an order defender, is more likely to adopt an exclusive institutional balancing strategy to cope with institutional challenges from rising powers such as China. China, as an order challenger, is more flexible in selecting both inclusive and exclusive institutional balancing strategies to change the rules and institutions in the current international order. Other pro-active second-tier powers, including Australia, Japan, and South Korea, can play a kingmaker role to set up new institutions, which can somehow neutralize the strategic competition between the United States and China. This inter-institutional balancing strategy, however, challenges the existing institutional arrangements centred on ASEAN in the Asia Pacific.

It is worth noting that the changing role conceptions of states will shape different institutional balancing strategies in the future. Trump's withdrawal from the TPP might signify a transformation of US national role conception from "order defender" to "order challenger" if Trump insists on his anti-globalization, "America First" policy. In contrast, China might 
become an "order defender" to safeguard existing open trade and investment regimes. Australia, Japan, and Korea might or might not be able or willing to play a kingmaker role. They might have to take sides in the context of the strategic competition between the United States and China. ASEAN's role in multilateralism should not be overestimated or underestimated.

The future of multilateralism and institutional balancing in the Asia Pacific will become more dynamic than ever before. The "unintended consequence" of institutional balancing among states, which can be seen as a positive externality of state competition through institutions, will be a more peaceful order transition in the international system. Although states still compete with one another through institutions, the outcome of institutional competition through institutions will be less violent than military competition, just because the latter is more likely to trigger military conflicts rooted in miscalculations and misperceptions. States might still live in the high church of Realpolitik. The complex institutional balancing among them, however, might create a more peaceful environment for them to avoid the so-called “Thucydides's Trap." 
Table 1. Role Conceptions and Institutional Balancing Strategies

\begin{tabular}{|c|c|c|c|}
\hline $\begin{array}{l}\text { Role } \\
\text { Conception }\end{array}$ & Motives & $\begin{array}{l}\text { Institutional } \\
\text { Balancing } \\
\text { Preference } \\
\end{array}$ & Examples \\
\hline $\begin{array}{l}\text { Order } \\
\text { Defender }\end{array}$ & $\begin{array}{l}\text { No change in the } \\
\text { current order; de- } \\
\text { legitimate rising } \\
\text { power's } \\
\text { challenges }\end{array}$ & $\begin{array}{l}\text { Exclusive } \\
\text { institutional } \\
\text { balancing against } \\
\text { the rising power }\end{array}$ & $\begin{array}{l}\text { - } \text { TPP (exclude China) } \\
\text { - } \text { AIIB (exclude itself } \\
\text { to de-legitimate } \\
\text { China's leadership } \\
\text { role) }\end{array}$ \\
\hline $\begin{array}{l}\text { Order } \\
\text { Challenger }\end{array}$ & $\begin{array}{l}\text { Establish its own } \\
\text { legitimacy base; } \\
\text { challenge/reform } \\
\text { the existing } \\
\text { order/maximize } \\
\text { its interests and } \\
\text { minimize costs }\end{array}$ & $\begin{array}{l}\text { Both inclusive } \\
\text { institutional } \\
\text { balancing and } \\
\text { exclusive } \\
\text { institutional } \\
\text { balancing }\end{array}$ & 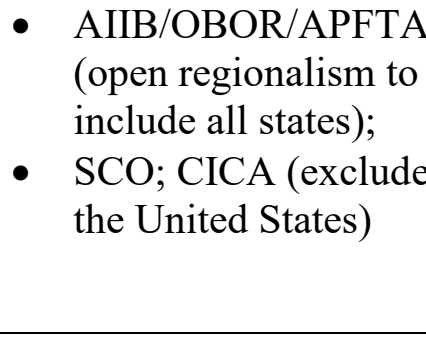 \\
\hline Kingmaker & $\begin{array}{l}\text { Maximize their } \\
\text { future position } \\
\text { and relevance; } \\
\text { existing } \\
\text { institutions are not } \\
\text { good enough }\end{array}$ & $\begin{array}{l}\text { Inter-institutional } \\
\text { balancing }\end{array}$ & $\begin{array}{ll}\text { - } & \text { Rudd's APC } \\
\text { - } & \text { Hatoyama's EAC } \\
\text { - } & \text { Park's NAPCI }\end{array}$ \\
\hline
\end{tabular}




\section{References:}

Allison, Graham. 2017. Destined for War: Can America and China Escape Thucydides's Trap? London. Houghton Mifflin Harcourt.

Anderlini, Jamil. "China Reinvigorates Regional Clubs to Counter Us Power." Financial Times, May 20, 2014.

Barnett, M., 1993. "Institutions, roles, and disorder: The case of the Arab states system.” International Studies Quarterly, 37(3): 271-296.

Beeson, M., 2003. "ASEAN plus three and the rise of reactional regionalism.” Contemporary Southeast Asia: A Journal of International and Strategic Affairs, 25(2): 251-268.

Bisley, N., 2017. "The East Asia summit and ASEAN: Potential and Problems." Contemporary Southeast Asia: A Journal of International and Strategic Affairs, 39(2), pp.265-272.

Blackwill, Robert D., and Ashley J. Tellis. Revising US Grand Strategy Toward China. Council on Foreign Relations, 2015.

Bull, H. 1977. The Anarchical Society: A Study of Order in World Politics. London: Macmillan.

Cantir, C. and Kaarbo, J., 2012. "Contested roles and domestic politics: reflections on role theory in foreign policy analysis and IR theory." Foreign Policy Analysis, 8(1): 5-24.

Edgecliffe-Johnson, Andrew et. al.. 2009. "Wen and Putin lecture western leaders: Chinese premier attacks 'blind pursuit of profit"” Financial Times, January 29.

Feng, Huiyun and Kai He. 2017. "China's Institutional Challenges to the International Order," Strategic Studies Quarterly 11 (4): 23-49.

Foot, R., 1998. "China in the ASEAN Regional Forum: Organizational processes and domestic modes of thought." Asian Survey, 38(5): 425-440.

Glaser, B. and Medeiros, E. 2007. "The changing ecology of foreign policy-making in China: the ascension and demise of the theory of 'peaceful rise'." The China Quarterly 190 (2007): 291-310

Goh, Evelyn. 2004. "The ASEAN Regional Forum in United States East Asian Strategy," The Pacific Review 17 (1): 47-69.

Goh, Evelyn. 2007. "Great powers and hierarchical order in Southeast Asia." International Security 32 (3): 113-157.

Harnisch, S., Bersick, S. and Gottwald, J.C. eds., 2015. China's International Roles: Challenging Or Supporting International Order? Routledge. 
Harnisch, Sebastian. 2012. "Conceptualizing in the Minefield: Role Theory and Foreign Policy Learning." Foreign Policy Analysis 8 (1): 47-69.

He, Kai and Stephen Walker. 2015. "Role Bargaining Strategies for China's Peaceful Rise.” Chinese Journal of International Politics 8 (4): 371-388.

He, Kai. 2008. "Institutional Balancing and International Relations Theory: Economic Interdependence and Balance of Power Strategies in Southeast Asia." European Journal of International Relations 14 (3): 489-518.

He, Kai. 2009. Institutional Balancing in the Asia-Pacific: Economic Interdependence and China's Rise. London and New York: Routledge.

He, Kai. 2014. "Facing the Challenges: ASEAN's Institutional Responses to China's Rise." Issues \& Studies 50 (3): 137-168.

He, Kai. 2015. "Contested Regional Orders and Institutional Balancing in the Asia Pacific." International Politics 52 (2): 208-222

Holsti, K. J. 1970. "National Role Conceptions in the Study of Foreign Policy." International Studies Quarterly 14 (3): 233-309.

Hughes, C.W., 2009. “Japan's response to China's rise: regional engagement, global containment, dangers of collision," International Affairs, 85(4): 837-856.

Hurd, Ian. 1999. "Legitimacy and Authority in International Politics.” International Organization 53(2): 379-408.

Ikenberry, G. John. 2001. After Victory: Institutions, Strategic Restraint, and the Rebuilding of Order after Major War. Princeton: Princeton University Press.

Ikenberry, G. John. 2008. "The Rise of China and the Future of the West: Can the Liberal System Survive?" Foreign Affairs, 87 (1): 23-35.

Ikenberry, G. John. 2011. Liberal Leviathan: The Origins, Crisis, and Transformation of the American World Order. Princeton: Princeton University Press.

Ikenberry, G.J., 2016. "Between the eagle and the dragon: America, China, and Middle State strategies in East Asia," Political Science Quarterly, 131(1), pp.9-43.

Jane Perlez, "U.S. Allies See Trans-Pacific Partnership as a Check on China." The New York Times, 6 October 2015.

Katsumata, H., 2010. ASEAN's cooperative security enterprise: norms and interests in the ASEAN regional forum. Springer.

Kennedy, Paul. 2010. “A Time to Appease.” The National Interest 108: 7-17.

Kenneth Lieberthal, and Jisi Wang. 2012. “Addressing Sino-US Strategic Distrust.” In The John L. Thornton China Center Monograph Series, no. 4, Brookings, 2012. 
Kissinger, Henry. 2014. World Order. New York: Penguin.

Lee, Y.W., 2006. "Japan and the Asian Monetary Fund: an identity-intention approach.” International Studies Quarterly, 50(2), pp.339-366.

Lipscy, P.Y., 2003. “Japan's Asian monetary fund proposal.” Stanford Journal of East Asian Affairs, 3 (1): 93-104.

Michael Green and Matthew P. Goodman. 2015. "After TPP: The Geopolitics of Asia and the Pacific," The Washington Quarterly 38 (4): 19-34.

Nye, Joseph. 2003. Understanding International Conflicts, fourth ed., New York: Longman.

Obama, B. 2015. "President Obama's Remarks in State of the Union Address," January 20, 2015. https://www.whitehouse.gov/the-press-office/2015/01/20/remarks-presidentstate-union-address-january-20-2015

Organski, A.F.K and Kugler, Jacek. 1980. The War Ledger. Chicago: Chicago University Press.

Organski, A.F.K. 1958. World Politics. New York: Knopf.

Paul Kennedy, “A time to appease.” The National Interest (2010) 108: 7-17

Simon, S., 2008. “ASEAN and multilateralism: The long, bumpy road to community," Contemporary Southeast Asia: A Journal of International and Strategic Affairs, 30 (2): 264-292.

Stryker, Sheldon and Statham. 1985. "Symbolic Interaction and Role Theory," in Handbook of Social Psychology, $3^{\text {rd }}$ ed., edited by Gardner Lindzey and Elliot Aronson, New York. Random House, pp. 311-378.

Stubbs, Richard., 2002. “ASEAN plus three: emerging East Asian regionalism?” Asian Survey, 42(3): 440-455.

Thies, C.G., 2012. "International socialization processes vs. Israeli national role conceptions: can role theory integrate IR theory and foreign policy analysis?" Foreign Policy Analysis, 8(1):25-46.

Thies, C.G., 2013. The United States, Israel and the Search for International Order: Socializing States. Routledge.

Thies, Cameron. 2010. "Role Theory and Foreign Policy.” In The International Studies Encyclopedia, edited by Robert Denmark. Oxford: Blackwell.

Walker, S.G., 1981. "The correspondence between foreign policy rhetoric and behavior: Insights from role theory and exchange theory," Systems Research and Behavioral Science, 26(3): 272-280. 
Walker, Stephen, ed. 1987. Role Theory and Foreign Policy Analysis. Durham, NC: Duke University Press.

Walker, Stephen. 2013. Role Theory and the Cognitive Architecture of British Appeasement Decisions: Symbolic and Strategic Interaction in World Politics. New York: Routledge.

Walker, Stephen. ed. 1987. Role Theory and Foreign Policy Analysis. Durham, NC: Duke University Press.

Zakaria, F., 2008. The Post-American World. New York: WW Norton \& Company.

Zhao, Suisheng. 2015. "A New Model of Big Power Relations? China-US strategic rivalry and balance of power in the Asia-Pacific." Journal of Contemporary China 24 (93): 377-397.

Zhou, Xiaochuan. 2009. "Reform international monetary system," China Daily. March, 25. http://www.chinadaily.com.cn/opinion/2009-03/25/content_7612847.htm 